\title{
Peningkatan Keterampilan Proses Sains Melalui Pembelajaran Berbasis Laboratorium Untuk Mewujudkan pembelajaran Berkarakter
}

\author{
Riswanto $^{1}$, dan Novi Ayu Kristiana Dewi ${ }^{2}$ \\ ${ }^{\mathrm{I}}$ Universitas Muhammadiyah Metro \\ ${ }^{2}$ Sekolah Tinggi Manajemen dan Informatika Pringsewu \\ Surat-e: rumbiariswan@gmail.com
}

Penelitian ini dilaksanakan di SMP N I Pekalongan, Lampung Timur. Berdasarkan hasil observasi siswa di kelasVIII dan wawancara dengan kepala Laboratorium IPA fisika diperoleh gambaran bahwa laboratorium disana memiliki alat-alat laboratorium yang cukup memadai namun belum dimanfaatkan secara maksimal. Upaya penyelesaiannya diterapkan pembelajaran berbasis laboratorium, yaitu suatu konsep pembelajaran yang memadukan antara kegiatan praktik dan pembelajaran teori di laboratorium. Tujuannya yaitu untuk mendorong siswa agar selalu aktif dan kreatif dalam menghasilkan keterampilan proses sains yang dimilikinya melalui kegiatan praktikum secara berkelanjutan. Subjek penelitian ini adalah siswa kelas VIII.5 yang terdiri dari 28 siswa. Penelitian ini merupakan penelitian Tindakan Kelas yang berlangsung selama 2 siklus, setiap siklusnya terdiri dari 3 kali pertemuan. Untuk keakuratan data yang diperoleh peneliti dibantu oleh 4 orang observer dalam mengamati keterampilan proses sains siswa dan karakter keaktifan siswa. Berdasarkan hasil penelitian, diperoleh sebanyak 85,7I\% siswa telah memiliki keterampilan proses sains dengan skor $\geq 7$ Idan sebanyak $67,86 \%$ siswa telah menunjukan karakter keaktifan dengan skor $\geq 72$. Dari hasil ini disimpulkan bahwa pembelajaran berbasis laboratorium mampu meningkatkan keterampilan proses sains serta mampu medorong terwujudnya karakter keaktifan siswa dalam bentuk karakter tanggung jawab menyusun laporan, merapikan alat, dan kerjasama antar kelompok. Saran dari peneliti, hendaknya dalam penerapan pembelajaran berbasis laboratorium guru selalu membimbing, memberikan perhatian dan mengontrol kinerja tiap kelompok praktikum.

This research was conducted at SMP N I Pekalongan, Lampung Timur. Based on the observations of students in class VIII and interviews with the head of Physics Laboratory of science got the picture that the laboratory there has enough laboratory equipment but not yet fully utilized. So as an effort to solve it applied laboratory-based learning, which is a learning concept that combines practical activities and theory learning in the laboratory. The goal is to encourage students to always be active and creative in fostering the science process skills they have through practicum activities in a sustainable manner. The subject of this research is the students of class VIII. 5 consisting of 28 students. This research is a study of Action Act which lasted for 2 cycles, each cycle consists of 3 times meeting. For the accuracy of data obtained by researchers assisted by 4 observers in observing the skills of students' science processes and student activeness. Based on the results of research, obtained as much as $85.7 \mathrm{I} \%$ of students have had the science process skills with a score of $\geq 7 \mathrm{I}$ and as many as $67.86 \%$ of students have shown the character of liveliness with a score of $\geq 72$. From this result, it is concluded that laboratory-based learning can improve the science process skills as well as able to encourage the realization of student activeness character by continuously. Suggestions from researchers should be in the application of teacher-based learning teachers always guide, give attention and control the performance of each group lab.

Kata kunci: Pembelajaran berbasis Laboratorium, keterampilan proses sains, karakter keaktifan 


\section{Pendahuluan}

Keberhasilan pembelajaran sangat ditentukan manakala pembelajaran tersebut mampu menumbuh kembangkan potensi-potensi yang dimiliki siswa sehingga siswa dapat memperoleh manfaatnya secara langsung dalam perkembangan pribadinya. Demi menciptakan pembelajaran fisika sebagaimana tersebut di atas maka diperlukan laboratorium dan media pembelajaran yang mendukung terciptanya perbelajaran fisika yang kreatif. Hasil pra survei yang telah peneliti lakukan diperoleh bahwa sebagian besar siswa belum mencapai ketuntasan dalam belajar, sedangkan dari hasil wawancara dengan guru fisika diperoleh informasi bahwa laboratorium IPA fisika memiliki alat-alat praktikum yang sangat memadai, tetapi alat-alat yang ada belum dimanfaatkan dan dikelola secara maksimal sehingga mengakibatkan banyak siswa yang belum mampu menggunakan dan mengoperasikan alat-alat dalam laboratorium IPA.

Berdasarkan kondisi tersebut maka diperlukan usaha untuk meningkatkan keterampilan siswa dalam menggunakan alat-alat laboratorium, maka pembelajaran berbasis laboratorium sebagai salah satu cara yang diharapkan dapat membantu siswa dalam meningkatkan keterampilan proses sains yang dapat membangun karakter siswa. Keterampilan proses sains sebagai pendekatan dalam pembelajaran sangat penting karena menumbuhkan pengalaman dalam proses belajar. Pengalaman yang dimaksudkan berupa bekal untuk menggunakan metode ilmiah dalam memperoleh pengetahuan baru atau mengembangkan pengetahuan yang telah dimilikinya melalui kegiatan praktikum, karena melalui kegiatan praktik siswa akan terlibat dalam penggunaan alat dan bahan, pengukuran, penyusun atau prakitan alat. Dalam pembelajaran berbasis laboratorium siswa diajak untuk dapat berperan aktif dalam mengembangkan potensi dan kemampuan yang ada pada dirinya. Bentuk peran aktif ini dikondisikan oleh guru melalui praktikum yang diadakan di laboratorium, sehingga pembelajaran akan menjadi lebih menyenangkan karena siswa terlibat langsung dalam mengkonstruksi pengetahuan yang mereka dapatkan. Selain itu dalam pembelajaran berbasis laboratorium guru sebagai fasilitator diharapkan mampu menumbuhkan sikap aktif siswa dalam memanfaatkan segala sumber belajar yang mereka butuhkan agar menjadi lebih berdaya guna bagi siswa.

\section{Kajian Pustaka}

Ref. [I] mengemukakan bahwa "Guru perlu merancang pembelajaran sains yang berbasis laboratorium, artinya pembelajaran konsep dilakukan bersamaan dengan kegiatan praktikum di laboratorium”. Di sini guru harus bisa membuat perencanaan pembelajaran yang berbasis laboratorium, namun tidak semua materi pembelajaran IPA fisika bisa dipraktikkan sehingga guru harus menganalisis materi mana yang harus dibelajarkan di laboratorium. Pengertian pembelajaran berbasis laboratorium lebih diperkuat lagi oleh Margono [2] yang menyatakan bahwa:

Laboratorium merupakan tempat yang penting dimana pengetahuan baru dihasilkan dan divalidasikan dalam bentuk eksperimen ilmiah. Disamping itu Margono juga menyatakan bahwa laboratorium juga merupakan tempat siswa dalam mendapatkan kesempatan melakukan pengalaman langsung dalam memecahkan masalah yang diangkat dari fenomena yang diamati atau teori yang mereka pelajari.

Maka dapat diambil sebuah pengertian bahwa pembelajaran berbasis laboratorium adalah pembelajaran konsep sains yang dipadukan dengan kegiatan praktikum di laboratorium untuk menumbuhkan pengalaman langsung pada diri peserta didik dalam memecahkan masalah dari fenomena dan teori yang dipelajari. Dalam hal ini guru harus mampu menganalisis materi yang akan dipraktikumkan di laboratorium dengan alasan materi praktikum yang lebih rumit dikerjakan di laboratorium sedangkan materi praktikum yang lebih ringan dikerjakan bersamaan dengan proses pembelajaran.

Rezba dalam [3] menyatakan bahwa keterampilan dasar proses sains meliputi kegiatan observasi, komunikasi, klasifikasi, kesimpulan sementara, dan ramalan atau prediksi.Hal ini diperjelas oleh Haryono [4] mengemukakan bahwa: Pembelajaran berbasis peningkatan keterampilan proses sains adalah bentuk pembelajaran yang mengintegrasikan keterampilan proses sains ke dalam rangkaian proses belajar mengajar guna mengarahkan siswa pada proses konstruksi pengetahuan secara mandiri.

Ref.[5] mengemukakan bahwa "Berbagai proses sains dapat dikembangkan dengan keterampilan di dalam laboratorium, baik dalam bentuk pengembangan keterampilan pengamatan, keterampilan merumuskan hipotesis, kemampuan merencanakan suatu percobaan melakukan eksperimen dan sebagainya". Jadi dapat dijelaskan bahwa keterampilan proses sains yaitu kemampuan siswa untuk menerapkan metode ilmiah dalam memahami, mengembangkan dan menemukan ilmu pengetahuan melalui proses mengobservasi, mengklasifikasi, memprediksi, mengukur, menyimpulkan, dan mengkomunikasikan yang dapat menimbulkan sikap ilmiah dalam diri siswa.

Pendidikan karakter dalam setting sekolah sebagai "pembelajaran yang mengarah pada penguatan dan pengembangan prilaku anak secara utuh yang didasarkan pada suatu nilai tertentu yang dirujuk oleh sekolah" yang berarti bahwa pendidikan karakter terintegrasi pada semua 
mata pelajaran yang diarahkan untuk mengembangakan perilaku siswa secara utuh.

Penelitian yang dilakukan oleh Dewi FivetaYuniarti menunjukkan bahwa ada korelasi yang positif dan tinggi antara keterampilan proses sains dan sikap ilmiah siswa kelas VIII SMP Negeri 32 Surabaya. Penelitian lain yang mendukung penelitian ini adalah Wijaya Kurnia, menyimpulkan bahwa karakter siswa menjadi lebih baik setelah mengikuti pelajaran fisika yang mengacu pada perangkat yang dikembangkan dan Ratna Puspitasari menyimpulkan bahwa perangkat penelitiannya cukup efektif dalam melatihkan keterampilan proses sains dan mendapat respon baik dari siswa. Penyataan di atas dipertegas dari hasil penelitian Ana Muawinaatin (mahasiswa Universitas Negeri Surabaya) menyimpulkan bahwa melalui keterampilan proses sains dapat membentuk empat karakter yang kuat diantaranya yaitu komunikatif, jujur, toleran dan bertanggungjawab (dalam hal ini pengutip mengambil indikator yang memiliki persentase hasil penelitian yang tinggi).

\section{Metode Penelitian PTK}

Berdasarkan permasalahan yang diteliti, peneliti mengambil jenis penelitian tindakan kelasyaitu sebuah kegiatan penelitian yang dilakukan di kelas sebagai upaya untuk mengkaji, merefleksi secara kritis suatu rencana pembelajaran terhadap kinerja (Performance) guru, interaksi guru dengan siswa, serta interaksi siswa dengan kelas. Secara garis besar terdapat empat tahapan yang lazim dilalui, yaitu (I) perencanaan, (2) pelaksanaan, (3) pengamatan, dan (4) refleksi. Ciri utama dari penelitian tindakan yaitu penelitian dilkukan secara bersiklus.Penelitian ini dilaksanakan di kelas VIII.5SMP Negeri I Pekalongan pada semester genap Tahun Pelajaran 20II/2012. Berikut adalah rancangan instrumen yang digunakan dalam penelitian ini.

Tabel I. Rancangan Instrumen Penelitian

\begin{tabular}{|c|c|c|c|c|}
\hline No & Variabel & Indikator & $\begin{array}{c}\text { Metode } \\
\text { Pengambilan } \\
\text { Data } \\
\end{array}$ & $\begin{array}{l}\text { Instru- } \\
\text { men }\end{array}$ \\
\hline I. & $\begin{array}{l}\text { Keterampi- } \\
\text { lan Proses } \\
\text { Sains }\end{array}$ & $\begin{array}{l}\text { Mengobservasi } \\
\text { Mengklasifikasi } \\
\text { Mengukur } \\
\text { Meyimpulkan } \\
\text { Mengkomunikasi } \\
\text { kan hasil. }\end{array}$ & $\begin{array}{l}\text { observasi } \\
\text { dengan } \\
\text { pengamatan } \\
\text { yang } \\
\text { dilkukan oleh } \\
4 \text { orang } \\
\text { observer } \\
\text { ketika } \\
\text { kegiatan } \\
\text { praktikum } \\
\text { berlangsung. }\end{array}$ & $\begin{array}{l}\text { Lembar } \\
\text { Observa- } \\
\text { si dan } \\
\text { catatan } \\
\text { lapangan }\end{array}$ \\
\hline 2. & $\begin{array}{l}\text { Pembelajar } \\
\text { anberbasisl } \\
\text { aboratori- } \\
\text { um }\end{array}$ & $\begin{array}{l}\text { Mengerjakan soal } \\
\text { tes awal dan tes } \\
\text { akhir pada tiap } \\
\text { siklus }\end{array}$ & $\begin{array}{l}\text { Tes awal dan } \\
\text { tes akhir }\end{array}$ & Tes \\
\hline
\end{tabular}

\begin{tabular}{|c|c|c|c|c|}
\hline No & Variabel & Indikator & $\begin{array}{c}\text { Metode } \\
\text { Pengambilan } \\
\text { Data }\end{array}$ & $\begin{array}{l}\text { Instru- } \\
\text { men }\end{array}$ \\
\hline 3 & $\begin{array}{l}\text { Karaktersis } \\
\text { wa }\end{array}$ & $\begin{array}{l}\text { Aktivitas dan } \\
\text { sikap siswa dalam } \\
\text { mengikuti proses } \\
\text { pembelajaran }\end{array}$ & $\begin{array}{l}\text { observasi } \\
\text { dengan } \\
\text { pengamatan } \\
\text { yang } \\
\text { dilkukan oleh } \\
4 \quad \text { orang } \\
\text { observer } \\
\text { ketika proses } \\
\text { pembelajaran } \\
\text { berlangsung }\end{array}$ & $\begin{array}{l}\text { Lembar } \\
\text { observasi } \\
\text { dan } \\
\text { catatan } \\
\text { lapangan }\end{array}$ \\
\hline
\end{tabular}

Sebelum penelitian dilaksanakan maka untuk memperoleh hasil pengukuran data yang valid (sahih) dan reliabel, maka penulis melakukan validitas instrument melalui penilaian guru ahli (exspert judment) yang terdiri dari 3 validator dan menguji coba terlebih dahulu instrumen yang telah disusun untuk mengetahui tingkat reliabilitasnya. Teknik analisis data yang digunakan dalam penelitian ini adalah pengamatan, tabulasi, tes, dan perbandingan data hasil terhadap indikator keberhasilan yang telah ditetapkan.

\section{Hasil Penelitian dan Pembahasan}

\section{Keterampilan Proses Sains}

Tabel 2. Data hasil ketercapaian keterampilan proses sains siswa

\begin{tabular}{|c|c|c|c|c|}
\hline \multirow[b]{2}{*}{ No } & \multirow{2}{*}{$\begin{array}{c}\text { Keterampilan } \\
\text { Dasar Proses } \\
\text { Sains }\end{array}$} & \multirow[b]{2}{*}{ Indikator } & \multicolumn{2}{|c|}{$\%$ Ketercapaian } \\
\hline & & & $\begin{array}{l}\text { Siklus } \\
\text { I }\end{array}$ & $\begin{array}{l}\text { Siklus } \\
\text { II }\end{array}$ \\
\hline \multirow[t]{3}{*}{$\mathrm{I}$} & \multirow{3}{*}{$\begin{array}{l}\text { Keterampilan } \\
\text { dalam } \\
\text { mengobservasi }\end{array}$} & $\begin{array}{l}\text { a. Mengetahui Fungsi } \\
\text { dan kegunaan alat }\end{array}$ & $\begin{array}{c}7 \mathrm{I}, 43 \\
\%\end{array}$ & $\begin{array}{c}91,67 \\
\%\end{array}$ \\
\hline & & $\begin{array}{l}\text { b. Menggunakan alat } \\
\text { sesuai dengan } \\
\text { prosedur }\end{array}$ & $\begin{array}{c}67,86 \\
\%\end{array}$ & $\begin{array}{c}83,33 \\
\%\end{array}$ \\
\hline & & $\begin{array}{l}\text { c. Merangkai alat } \\
\text { sesuai dengan } \\
\text { gambar rangkaian }\end{array}$ & $\begin{array}{c}61,90 \\
\%\end{array}$ & $\begin{array}{c}90,48 \\
\%\end{array}$ \\
\hline \multirow[t]{3}{*}{2} & \multirow[t]{3}{*}{$\begin{array}{l}\text { Keterampilan } \\
\text { dalam } \\
\text { mengklasifikasi }\end{array}$} & $\begin{array}{l}\text { a. Memilih alat yang } \\
\text { tepat yang akan } \\
\text { digunakan dalam } \\
\text { percobaan }\end{array}$ & $\begin{array}{c}55,95 \\
\%\end{array}$ & $\begin{array}{c}86,90 \\
\%\end{array}$ \\
\hline & & $\begin{array}{l}\text { b. Mengetahui } \\
\text { perbedaan dan } \\
\text { persamaan dari alat. }\end{array}$ & $\begin{array}{c}67,86 \\
\%\end{array}$ & $\begin{array}{c}84,52 \\
\%\end{array}$ \\
\hline & & $\begin{array}{l}\text { c. Membandingkan } \\
\text { alat. }\end{array}$ & $\begin{array}{c}57, \mathrm{I} 4 \\
\%\end{array}$ & $\begin{array}{c}86,90 \\
\%\end{array}$ \\
\hline \multirow[t]{4}{*}{3} & \multirow{4}{*}{$\begin{array}{l}\text { Keterampilan } \\
\text { dalam } \\
\text { melakukan } \\
\text { pengukuran }\end{array}$} & $\begin{array}{l}\text { a. Mengumpulkan } \\
\text { data-data yang }\end{array}$ & 57,14 & 76,19 \\
\hline & & $\begin{array}{l}\text { relevan dengan } \\
\text { indera }\end{array}$ & $\%$ & $\%$ \\
\hline & & $\begin{array}{l}\text { b. Menuliskan hasil } \\
\text { pengamatan yang } \\
\text { diperoleh ke dalam } \\
\text { tabel }\end{array}$ & $\begin{array}{c}5 \mathrm{I}, \mathrm{I} 9 \\
\%\end{array}$ & $\begin{array}{c}75,00 \\
\%\end{array}$ \\
\hline & & $\begin{array}{l}\text { c. Menghitung nilai } \\
\text { yang diperlukan }\end{array}$ & $\begin{array}{c}50,00 \\
\%\end{array}$ & $\begin{array}{c}75,00 \\
\%\end{array}$ \\
\hline
\end{tabular}




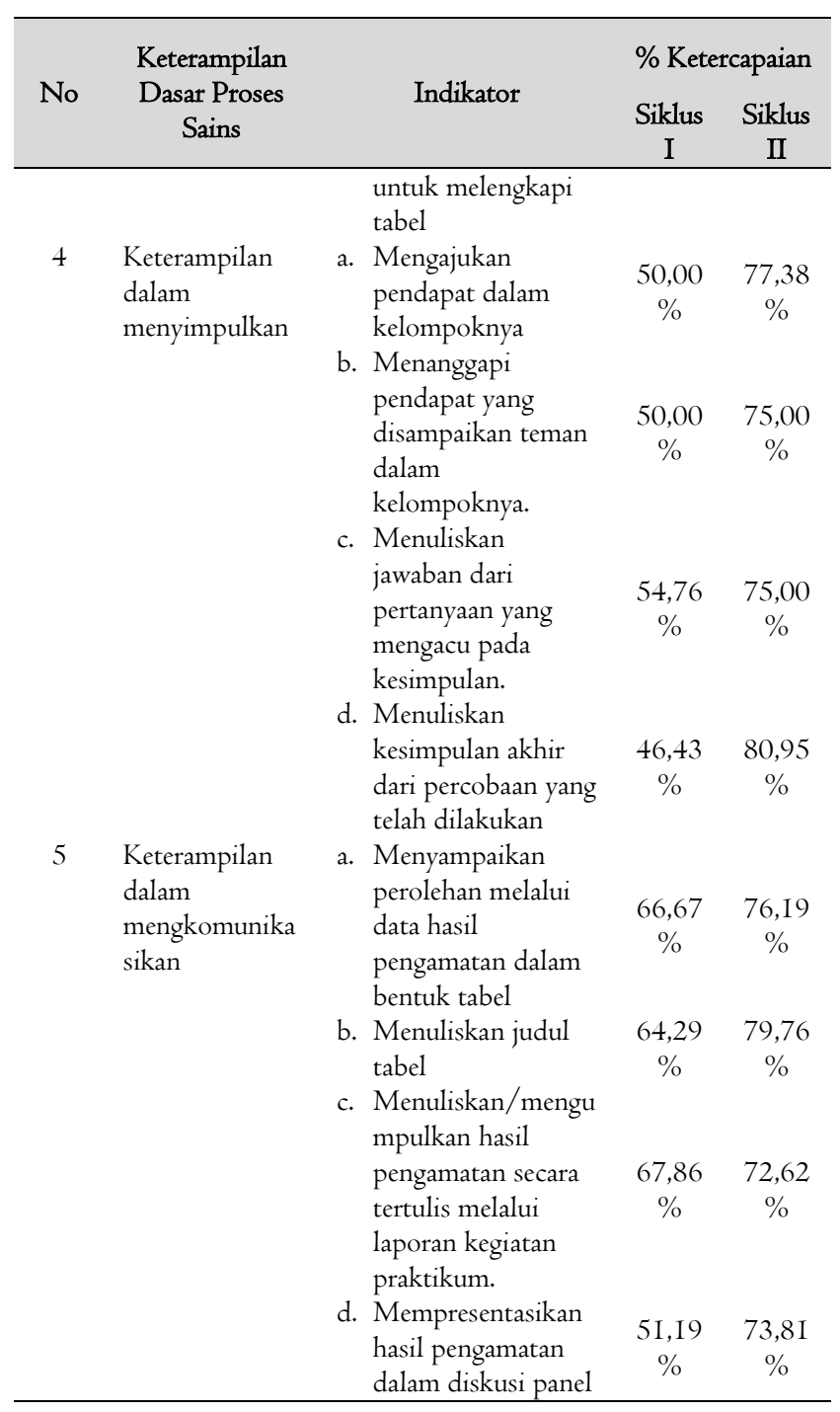

Berdasarkan perolehan hasil di atas, dapat dijelaskan bahwa persentase rata-rata kriteria untuk masing-masing indikator pada siklus I belum mencapai target yang ditetapkan yaitu $70 \%$ untuk masing-masing indikator. Sebagai tindak lanjutnya dilaksanakan refleksi untuk memperbaiki kekurangan pada siklus sebelumya dan dilakukan pengamatan kembali pada siklus II, dan diperoleh hasil persentase rata-rata untuk masing-masing indikator telah mencapai target.

\section{Karakter Siswa}

\begin{tabular}{clcc}
\hline \multirow{2}{*}{ No } & \multicolumn{2}{c}{ Indikator aktivitas } & \multicolumn{2}{c}{ \% Rata-rata Ketercapaian } \\
& Siklus I & Siklus II \\
\hline \multirow{2}{*}{ I } & Menulis & $70,84 \%$ & $87,50 \%$ \\
& Berdiskusi & $44,64 \%$ & $67,86 \%$ \\
& Bertanya & $45,24 \%$ & $66,67 \%$ \\
\multirow{2}{*}{2} & Menjawab Pertanyaan & $61,11 \%$ & $69,64 \%$ \\
& Mengemukakan ide/gagasan & $48,81 \%$ & $69,05 \%$ \\
& Menanggapi Jawaban Teman. & $44,05 \%$ & $70,83 \%$ \\
\multirow{2}{*}{3} & Komitmen terhadap tugas & $58,93 \%$ & $70,24 \%$ \\
& Perhatian terpusat pada materi & $69,64 \%$ & $76,79 \%$ \\
& Bersemangat & $57,74 \%$ & $67,86 \%$ \\
& Percaya diri & $60,12 \%$ & $66,67 \%$ \\
\hline
\end{tabular}

Berdasarkan hasil pengamatan aktivitas siswa pada pertemua I dan 3 diperoleh rata-rata untuk siklus I aktivitas menulis memiliki rata-rata persentase ketercapaian kompetensi yang mencapai target dan aktivitas yang lainnya bervariasi sesuai dengan kemampuan siswa. Dengan target sebesar $70 \%$ untuk masing-masing aktivitas. Sedangkan pada siklus II pada pertemuan 3 diperoleh aktivitas yang menjadi indikator telah mencapai target yang diharapkan dengan rata-rata persentase pencapaian kompetensi yang relatif jauh lebih besar dari siklus sebelumnya. Dari tindakan yang dilakukan melalui 2 siklus yang terkondisi dengan kegiatan praktek dan pemberian teori, jika kita melihat hasil yang diperoleh di atas maka kita dapat menyatakan bahwa melalui peningkatan aktivitas tersebut akan mampu membentuk karakter siswa secara kontinu dengan mengangap bahwa karakter dapat dibentuk melalui aktivitas tanggung jawab siswa dalam merapikan alata percobaan, menposisikan alat sesuai dengan tempatmnya, dan bekerjasama dengan kelompoknya

\section{PEMBAHASAN}

Berdasarkan hasil analisis lembar observasi dan tes yang telah diberikan dalam pembelajaran berbasis laboratorium diperoleh kecenderungan keterampilan proses sains dalam membangun karater siswa ditunjukan dengan data grafik sebagai berikut:

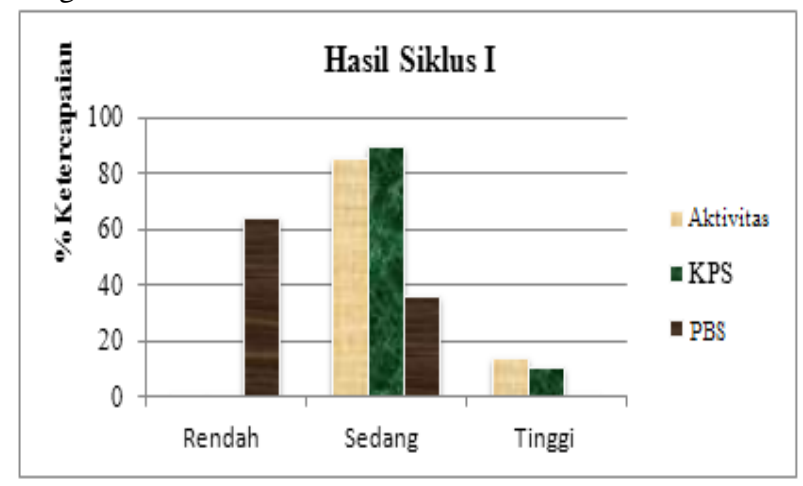

Gambar I. Kecenderungan Keterampilan Proses sains Siswa Dalam Pembelajaran Berbasis Laboratorium Dalam Membangun Karakter Siswa Pada Siklus I 


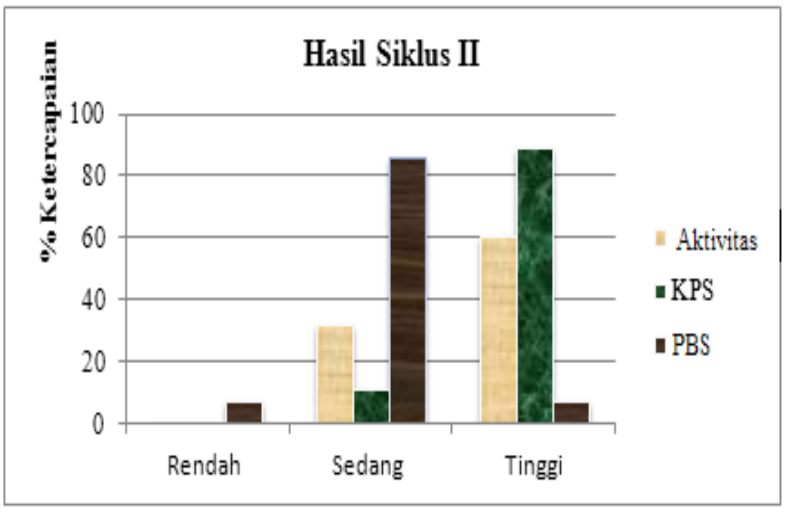

Gambar 2. Kecenderungan Keterampilan Proses sains Siswa Dalam Pembelajaran Berbasis Laboratorium Dalam Membangun Karakter Siswa Pada Siklus II.

Berdasarkan Grafik di atas, dapat dilihat bahwa meningkatnya keterampilan proses sains siswa cenderung diikuti oleh meningkatnya aktivitas siswa. Peningkatan hasil tersebut dikarenakan pada pembelajaran berbasis laboratorium menerapkan pembelajaran teori yang dipadukan denganpraktik laboratorium. Dimana praktik laboratorium menekankan pada kegiatan pembelajaran yang dikaitkan dengan situasi dunia nyata sehingga dapat membuka wawasan berpikir yang beragam dari seluruh peserta didik. Siswa yang memiliki kemampuan akademik tinggi berperan sebagai tutor bagi teman-temannya yang memiliki kemampuan akademik lebih rendah.

Kendala-kendala yang ditemui pada penelitian ini yaitu keramaian pada saat melakukan praktikum karena asyik berkeliling ke kelompok lain melihat aktivitas kelompok lain. Namun secara teknis pada siklus II siswa telah merasakan manfaat pembelajaran berbasis laboratorium dimana siswa menjadi lebih mudah belajar, lebih paham dengan konsep yang dipelajari, dan lebih aktif. Karena dalam pelaksanaannya siswa dapat mengembangkan keterampilan proses sainsnya dalam mengobservasi, mengklasifikasi, mengukur, menyimpulkan dan mengkomunikasikan. Dengan adanya keterampilan proses sains ini mampu mendorong siswa untuk aktif dalam menulis, berdiskusi, bertanya, menjawab, menanggapi jawaban teman, memperhatikan penjelasan guru, dan kerjasama dalam kelompok. Hasil penelitian ini menunjukkan bahwa pembelajaran berbasis laboratorium yang disertai praktik laboratorium dapat meningkatkan keterampilan proses sains siswa sehingga mampu mewujudkan pembelajaran yang aktif, kreatif, efektif dan menyenangkan bagi siswa dalam artinya membangun karakter siswa yang kuat.

Selain itu tanggapan siswa juga diperlukan untuk mendapatkan umpan balik terhadap proses pembelajaran berbasis laboratorium yang memadukan antara teori dan praktik laboratorium. Tanggapan ini diberikan dengan tujuan untuk melihat antusiame dan respon siswa terhadap pembelajaran berbasis laboratorium. Tanggapan siswa terhadap proses pembelajaran yang telah dilakukan selama pembelajaran diperoleh melalui hasil angket.

Berdasarkan hasil analisis angket yang telah diperoleh pada akhir kegiatan pembelajaran ini, secara keseluruhan sebanyak 90\% siswa tertarik dengan pelajaran fisika yang menggunakan pembelajaran berbasis laboratorium Siswa beralasan bahwa pembelajaran berbasis laboratorium dapat membuat materi pelajaran lebih mudah dipahami dan lebih menyenangkan sehingga lebih termotivasi untuk belajar. Sedangkan siswa yang tidak tertarikberalasan karena membuat suasana kelas ramai. Alasan tersebut di atas dapat dibuktikan dengan hasil angket bahwa sebanyak $86,6 \%$ siswa lebih mudah memahami materi, 93,3\% lebih termotivasi belajar, $86,6 \%$ siswa lebih senang dan selalu berpartisipasi aktif dalam kegiatan belajar maupun kegiatan praktik di laboratorium, dan sebanyak $90 \%$ siswa menyukai suasana kelasnya sekarang. Namun, dalam angket yang diberikan diperoleh bahwa sebagian siswa sebanyak 83,3\% juga masih merasa kesulitan dalam kegiatan praktikum karena dalam kegiatan praktik setiap kelompok siswa membutuhkan perhatian yang lebih. Maka untuk itu guru harus mampu untuk bekerja keras dengan mengontrol siswa tiap kelompok.

\section{Kesimpulan}

Berdasarkan data hasil penelitian tindakan kelas yang telah dilakukan dengan menerapkan pembelajaran berbasis laboratorium yang memadukan teori dan praktik di laboratorium maka dapat disimpulkan bahwa meningkatnya keterampilan proses sains siswa kelas VIII SMP Negeri I Pekalongan pada materi pokok cahaya, ditunjukan dengan peningkatan keterampilan dalam mengobservasi alat, mengklasifikasi alat, melakukan pengukuran, menyimpulkan hasil percobaan, dan mengkomunikasikan hasil percobaan. Berdasarkan hasil penelitian, diperoleh sebanyak $85,71 \%$ siswa telah memiliki keterampilan proses sains dengan skor $\geq 7 \mathrm{Idan}$ sebanyak $67,86 \%$ siswa telah menunjukan karakter keaktifan dengan skor $\geq 72$. Dari hasil ini disimpulkan bahwa pembelajaran berbasis laboratorium mampu meningkatkan keterampilan proses sains serta mampu medorong terwujudnya karakter keaktifan siswa dalam bentuk karakter tanggung jawab menyusun laporan, merapikan alat, dan kerjasama antar kelompok.

Saran bagi guruguna mengoptimalisasikan pemanfaatan laboratorium maka perlu diterapkan pembelajaran berbasis laboratorium untuk mengembangkan keterampilan proses sains dan aktivitas siswa, merencanakan alokasi waktu yang tepat agar setiap tahapan pembelajaran dapat terlaksana secara keseluruhan, memberikan dorongan dan motivasi, memberi perhatian, dan mengontrol kinerja tiap kelompok. 


\section{Ucapan Terimakasih}

Ucapan terima kasih kepada pihak sekolah SMP Negeri I Pekalongan Lampung Timur yang telah menyediakan tempat dan memberikan izin kepada kami untuk dapat melalkukan penelitian di Sekolah tersebut.

\section{Kepustakaan}

[I] Widhy, Purwanti. Pembelajaran IPA Berbasis Laboratorium. Makalah disajikan dalam Pelatihan Pembelajaran MIPA Berbasis Laboratorium Prodi Pendidikan IPA UNY. Jogjakarta: I8 Januari 2010.

[2] Margono, Hadi. Metode Laboratorium. Malang: FMIPA Malang, 2000

[3] Mahmudin. Komponen Penilaian KPS, 2010. Website:. (http://mahmudinbelajar jadi manusi.worpress.com. diakses II Desember 201 I)

[4] Haryono. Jurnal Pendidikan Dasar: (online).(Model Pembelajaran Berbasis Peningkatan Keterampilan Proses Sains.pdf). Dosen Fakultas Ilmu Pendidikan (FIP) dan Program Pascasarjana (PPs) UNNES, 2006.

[5] Surachman. Dasar-Dasar Pengelolaan Laboratorium Biologi. Jogjakarta: FPMIPA IKIP Jogja, 1987. 